\title{
DESIGN AND DEVELOPMENT OF PYROLYSIS BATCH REACTOR AND CHARACTERIZATION OF TIRE PYROLYSIS OIL USING GC/MS AND FT IR
}

\author{
Hariram. $V^{1}$, Mohammed Ismail M.A ${ }^{2}$ \\ ${ }^{l}$ Department of Automobile Engineering, Hindustan Institute of Technology \& Science, Hindustan University, \\ Chennai, Tamil Nadu, India \\ ${ }^{2}$ Department of Automobile Engineering, Hindustan Institute of Technology \& Science, Hindustan University, \\ Chennai, Tamil Nadu, India
}

\begin{abstract}
Owing to the increased fuel crises and rapid growth of transportation sector, it is very much necessary to identify and alternative to petroleum feed stocks. On the other hand disposal of solid waste material raises the hazard of environmental pollution. In order to bridge these gaps, a pyrolysis batch reactor was designed and fabricated in the present investigation with an overall dimension of 400 X 200 X $458 \mathrm{~cm}$ and handling capacity of $10 \mathrm{kgs}$ per cycle. The yield of TPO was optimized with reaction temperature to produce high quantity of gaseous outputs. Elemental analysis, Gas chromatography Mass spectrometry analysis and Fourier transform infrared analysis were carried out and found that limonene was the major compound in the TPO. The FT IR analysis also revealed the presence of aliphatic and aromatic compounds in the TPO. The physio-chemical properties of TPO were determined using Indian standard 1448 standards and were found to usable in internal combustion engine as treated TPO and blends of TPO with straight diesel.
\end{abstract}

Keywords: Pyrolysis, Elemental analysis, Limonene, Calorific value, Sulphur. $* * *$

\section{INTRODUCTION}

The transportation sector faces a major crisis and huge shortage of petroleum-diesel for its application. It is very much necessary for the researchers to find an alternative way for the fuel to be used effectively in internal combustion engines. With similar or better maneuverability and efficiencies on comparison with diesel on the other hand, disposal of solid waste material causes air, water and soil pollution to a great extent which may be due to higher population density and increased industries in many developing countries. Therefore, it is necessary to bridge the gap between solid waste management and fuel for internal combustion engine. It was estimated that many developing and developed countries generate nearly 32 tons of unusable tires every year which was due to enhanced development in the transportation sector. An automobile tire contains nonbiodegradable combination of many rubber, metal strips \& cords, carbon black and other inorganic and organic materials. It is extremely difficult to dispose the above combinations of material without causing environmental hazards. There are many methods illustrated for solid waste disposal such as retreading, oxidizing, hydrogenation and high temperature pyrolysis. Generally pyrolysis refers to decomposition of inorganic and organic material at elevated temperature between $350^{\circ} \mathrm{C}$ to $750^{\circ} \mathrm{C}$ in the absence of oxygen and the resulting compounds of these reactions may be in the form of liquid, solid and gaseous state. This transition stage may be temporary or permanent which yields solid char which is used as landfills and the gases are used are used in automotive fuels on condensation [3]. A new approach in the heating system was developed to recover the hydrocarbons from waste tire in a fixed bed reactor under inert atmosphere. It was noticed that at $475^{\circ} \mathrm{C}$, the pyrolysis reaction yielded optimum liquid/gas at a vapor residence of $5 \mathrm{sec}$. The physio-chemical analysis includes elemental analysis, gas chromatography mass spectrometry, Fourier transform infrared analysis and distillation showed the presence of hydrocarbon limonene, short and long chain alkyl, aromatic hydrocarbons in various quantities [11-13].

Bicycle waste tire was used in a semi batch pyrolytic reactor at $450^{\circ} \mathrm{C}$ to $650^{\circ} \mathrm{C}$ with a heating rate of $20^{\circ} \mathrm{C}$ per min which yield optimum liquid output at $600^{\circ} \mathrm{C}$. The reaction time, reaction temperature and yield of liquid/gas were analyzed in detail and the TPO was characterized using thermo gravity, FT IR, and GC MS techniques. It was noticed that the calorific value of TPO was very much comparable with straight diesel and can be used in IC engine without any modifications [4]. Few studies were also reported mainly on thermogravimetric analysis because that was the only technique available in earlier period to estimate the conversion rate of solid to liquid and liquid to gases in the tire pyrolysis process. This process showed weight loss pattern at different temperature of pyrolysis process which may be evident as the decomposition procedure were styrene butadiene rubber decomposed at higher temperature. Tire pyrolysis was considered to be non-conventional method for waste disposal in which the reaction was completed at $550^{\circ} \mathrm{C}$ of reaction temperature. It was 
suggested that pyrolysis was very much suitable in recovering oil from waste tires and the proximate and elemental analysis revealed that the oil was most suited for the usage in internal combustion engine. In this process the solid residue of $40 \%$, liquid residue of $50 \%$ and gaseous residue of $10 \%$ were noticed $[1,14,17]$.

In the present experimental study, the design and fabrication of tire pyrolysis batch reactor was carried out and characterization of TPO was analyzed using GC/MS, FT IR and elemental analysis. The state of change from solid to liquid and liquid to gases were noticed at various temperatures conditions. The physio-chemical properties of TPO and its blend with straight diesel were also studied in detail to understand its application in internal combustion engine.

\section{MATERIALS AND METHODS}

$20 \mathrm{kgs}$ of waste automotive tire were collected from a local vendor in Chennai. The major composition of waste tire was found to be vulcanized rubber, metal cords and beadings, carbon black, sulphur, oxides of zinc and textile fabric as detailed in Table (1) with the comparison of LMV's and HMV's tires. The metal beading in the tire was carefully removed and made into small square pieces at $4 \mathrm{~cm} \mathrm{X} 4 \mathrm{~cm}$ with the help of cutting instruments. The waste rubber pieces were washed continuously in the flowing water for $1 \mathrm{hr}$ at $45^{\circ} \mathrm{c}$ to remove the impurities and coating materials. This process was repeated for two more times to confirm the removal of impurities which could affect the pyrolysis process [2]. The Figure (1) shows the block flow diagram of recovering the TPO from waste tire in the pyrolysis batch reactor. The reaction yielded three compounds namely solid char, TPO and gases.

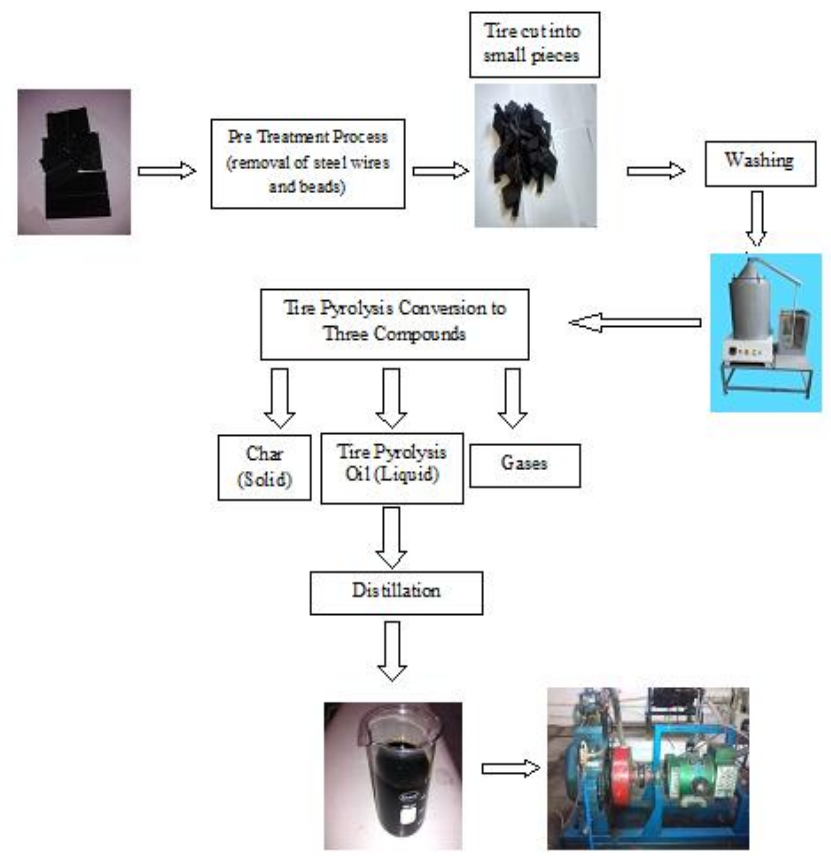

The distillation process was carried out on the raw TPO for its usage in internal combustion engine. The composition of waste tire used in this experimental investigation is given in Table (1) with the comparison of LMV's and HMV's tires. It can be noticed that the content of rubber was similar were as the sulphur content was $0.3 \%$ higher. All the other materials were found to be similar to LMV's and HMV's tire as shown in Table (1). Physio-chemical analysis, Elemental analysis, Gas chromatography Mass spectrometry and Fourier transform infrared spectrometry analyses were carried out on the tire pyrolysis oil to understand its properties and characteristics for its usage in internal combustion engine. JEOL Gate GC Mate 2 data system with high resolution and double focusing type and Fourier transform infrared spectrometry were used to study the GC/MS pattern and FTIR pattern respectively.

Table 1 Comparison of material composition of Waste tires

\begin{tabular}{|c|c|c|c|}
\hline Materials & $\begin{array}{l}\text { Waste } \\
\text { tire (wt } \\
\%)\end{array}$ & $\begin{array}{l}\text { LMV } \\
\text { Tires in } \\
(\text { wt \%) }\end{array}$ & $\begin{array}{l}\text { HMV } \\
\text { Tires in } \\
(\text { wt \%) }\end{array}$ \\
\hline Rubber & 46 & 48 & 45 \\
\hline Carbon black & 21.7 & 21.5 & 22 \\
\hline Metal & 17 & 15.5 & 25 \\
\hline Textile & 5.6 & 5.5 & - \\
\hline Zinc oxide & 1.1 & 1 & 2 \\
\hline Sulphur & 1.3 & 1 & 1 \\
\hline Additives & 7.3 & 7.5 & 5 \\
\hline
\end{tabular}

\section{EXPERIMENTATION}

The pyrolysis batch reactor was designed using Catia software with the overall dimension of 400 X 200 X 458 cms as shown in the Figure (2). The reactor consists of two cylinders; a convergent top, exhaust chute, condensation chamber, L shaped oil outlet, three induction coil and a temperature controller. Stainless sheet metal was used for inner and outer cylinders which are placed over 3 heating induction coils. The generation of heat was through power supply which can elevate the temperature upto $750^{\circ} \mathrm{C}$ by an increment of $15^{\circ} \mathrm{C} / \mathrm{min}$.

The inner and outer cylinders are separated by $20 \mathrm{~mm}$ glass wool which acts as an insulator to reduce the wastage of heat energy. A metal chute of $20 \mathrm{~mm}$ diameter, inclined at $12^{\circ}$ was connected to the reactor outlet and directed towards the condensation chamber as shown in Figure (3). The condensation chamber was filled with 13 liters of cold water to convert the smoke/gas into TPO. After condensation, the TPO occupies the upper layer in the condensation chamber and are separated from water with the help of $\mathrm{L}$ shaped metallic arrangement [5,10]. The detailed cross-sectional view and actual pictorial view of the pyrolysis batch reactor is shown in Figure (3).

Fig 1 Block diagram for TPO recovery 

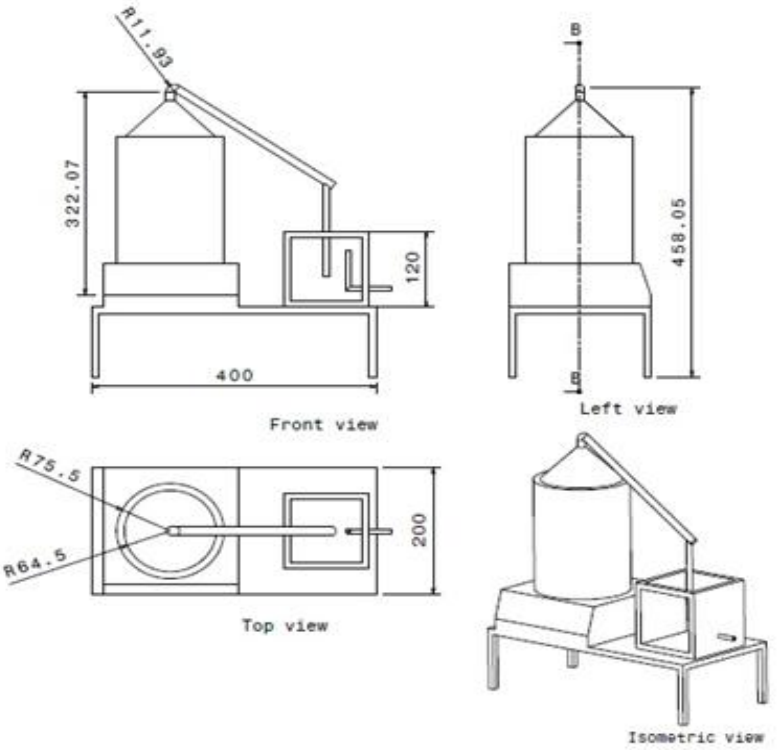

Fig 2 Design of pyrolysis batch reactor

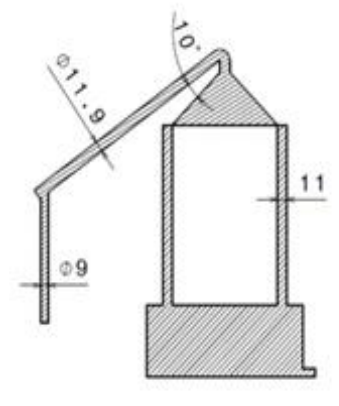

Section View B-B

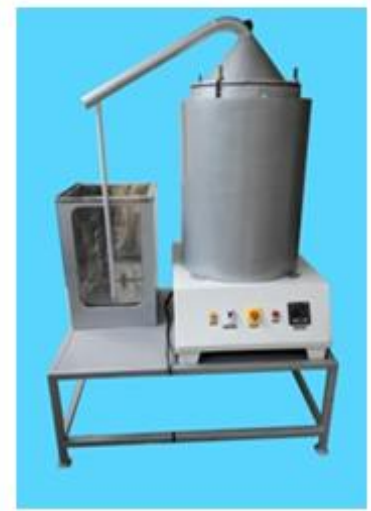

Fig 3 Sectional and pictorial view of pyrolysis batch reactor

The raw tire pyrolysis oil was treated in three stages namely de-moisturizing, de-sulphurisation, and distillation process to remove excess moisture, sulphur and sludge respectively before its usage in compression ignition engine. During the de-moisturizing process, the raw TPO was heated upto $125^{\circ} \mathrm{C}$ to remove excess moisture which was followed by de-sulphurisation process by adding $10 \%$ concentrated $\mathrm{H}_{2} \mathrm{SO}_{4}$ at $70^{\circ} \mathrm{C}, 250 \mathrm{rpm}$ for $24 \mathrm{hrs}$. During this settling period, the impurities and sulphur content is formed as sludge and occupies the bottom layer. The treated TPO was carefully separated from the sludge and subjected to distillation process upto $240^{\circ} \mathrm{C}$. By this process, $92 \%$ of TPO was recovered which can be used in compression ignition engine $[6,8]$.

\section{RESULT AND DISCUSSIONS}

\subsection{Effect of Reactor Temperature on the Products}

\section{Yield}

The Table (2) shows the variation in yield of solid char, liquid and gases at $300^{\circ} \mathrm{C}, 350^{\circ} \mathrm{C}, 400^{\circ} \mathrm{C}$ and $450^{\circ} \mathrm{C}$ respectively on the pyrolysis batch reactor. It was noticed the yield of soil char was reduced with the increase in temperature (i.e) yield of solid char at $300^{\circ} \mathrm{C}, 350^{\circ} \mathrm{C}, 400^{\circ} \mathrm{C}$ and $450^{\circ} \mathrm{C}$ was found to be $47.5,45.5,45.0$ and $41.5 \%$ by weight respectively. The yield of liquid was also almost similar to solid char showing very minimal variations. The gases yield was found to be higher with the increase in temperature of the reactor which may be due to change in transition state at higher temperature. At $300^{\circ} \mathrm{C}, 350^{\circ} \mathrm{C}$, $400^{\circ} \mathrm{C}$ and $450^{\circ} \mathrm{C}$ of reactor temperature, the gas yield was noticed to be $6.5,10.0,12.5$ and $18.5 \%$ by weight respectively. Figure (4) also exhibited the yield of gases was increased with reduction in solid char and liquid at elevated temperatures [16].

Table 2 Comparison of product yield at different reactor temperature

\begin{tabular}{|l|l|l|l|l|}
\hline \multirow{2}{*}{$\begin{array}{l}\text { Types } \\
\text { Products }\end{array}$} & \multicolumn{4}{|l|}{$\begin{array}{l}\text { Products yield at different reactor } \\
\text { temperature }\end{array}$} \\
\cline { 2 - 5 } & $\mathbf{3 0 0}^{\mathbf{C}} \mathbf{C}$ & $\mathbf{3 5 0}^{\mathbf{}} \mathbf{C}$ & $\mathbf{4 0 0}^{\mathbf{}} \mathbf{C}$ & $\mathbf{4 5 0}^{\mathbf{C}} \mathbf{C}$ \\
\hline Solid char & 47.5 & 45.5 & 45 & 41.5 \\
\hline Liquids & 46 & 44.5 & 42.5 & 40 \\
\hline Gases & 6.5 & 10 & 12.5 & 18.5 \\
\hline
\end{tabular}

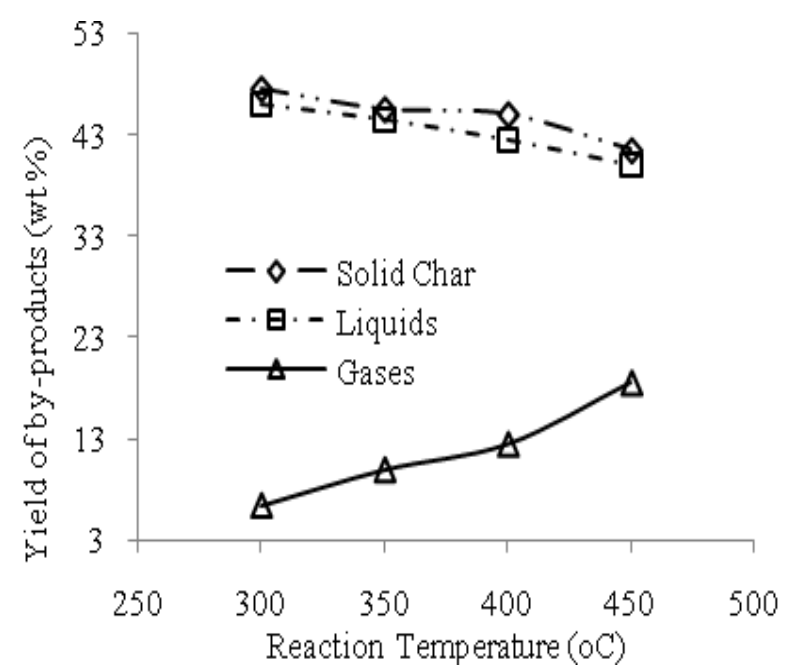

Fig 4 Comparison between reaction temperature and TPO yield

\subsection{Elemental Analysis of TPO}

The elemental analysis was carried out on the Tire pyrolysis oil to identify the presence of various elements, organic and in-organic materials. It was noticed that TPO contained $81.48 \%, 6.22 \%, 0.23 \%, 1.68 \%, 7.69 \%$ and $2.7 \%$ by weight of carbon, hydrogen, nitrogen, sulphur, oxygen and inorganic ashes respectively as shown in Table (3).

Table 3 Elemental composition of TPO

\begin{tabular}{|l|l|}
\hline Elements & Composition $(W t ~ \%)$ \\
\hline Carbon & 81.48 \\
\hline Hydrogen & 6.22 \\
\hline Nitrogen & 0.23 \\
\hline Sulphur & 1.68 \\
\hline Oxygen & 7.69 \\
\hline Ashes (Inorganic) & 2.7 \\
\hline
\end{tabular}




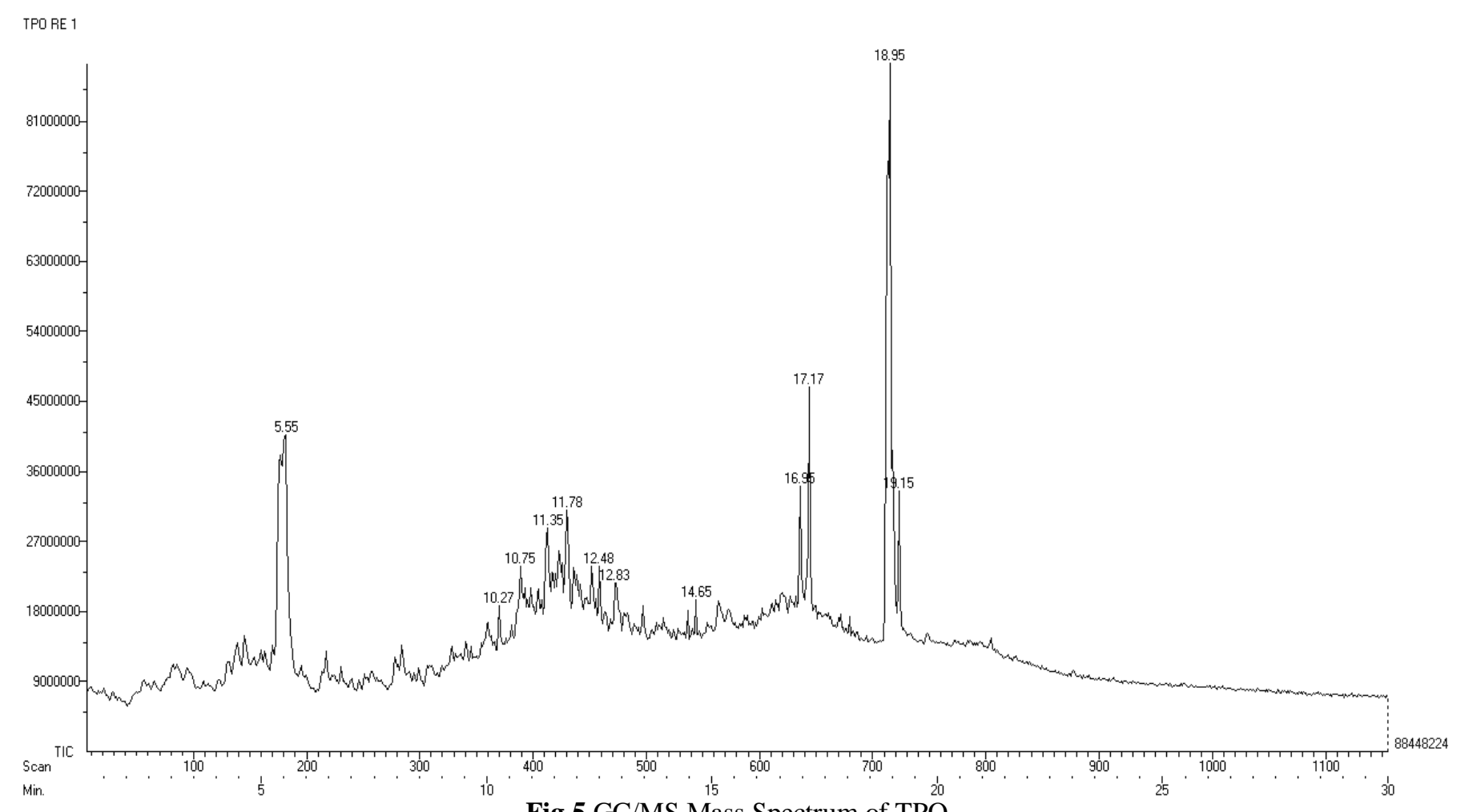

Fig 5 GC/MS Mass Spectrum of TPO

Table 4 FT IR analysis of TPO

\begin{tabular}{|l|l|}
\hline $\begin{array}{c}\text { Frequency of } \\
\text { wavelength } \mathbf{( \mathbf { c m } ^ { - 1 } \mathbf { 1 } )}\end{array}$ & \multicolumn{1}{c|}{ Compound functional group } \\
\hline $710-815$ & $\mathrm{C}-\mathrm{H}_{\text {Bend }}$ (Alkenes) \\
\hline $852-1045$ & $\mathrm{C}=\mathrm{C}_{\text {Stretch }}$ (Alkenes) \\
\hline $1220-1320$ & $\mathrm{C}-\mathrm{S}_{\text {Stretch }}$ (Amines) \\
\hline $1380-1590$ & $\mathrm{C}-\mathrm{H}_{\text {Bend }}$ (Alkanes) \\
\hline $1620-1820$ & $\mathrm{C}=\mathrm{C}_{\text {Stretch }}$ (Aromatic Compounds) \\
\hline $1905-2150$ & $\mathrm{C}=\mathrm{H}$ (Phenyl ring substitute) \\
\hline $2250-2620$ & $\mathrm{C}-\mathrm{H}_{\text {Stretch }}$ (Aldehydes) \\
\hline $2720-2940$ & $\mathrm{C}-\mathrm{H}_{\text {Stretch }}$ \\
\hline $2985-3015$ & $\mathrm{C}=\mathrm{H}_{\text {Bend }}$ \\
\hline $3080-3150$ & $\mathrm{C}=\mathrm{C}_{\text {Stretch }}$ (Alkenes) \\
\hline
\end{tabular}

GC/MS analysis was carried out using JEOL Gate GC mate 2 to identify the various compounds present in TPO. $2 \mathrm{ml}$ of TPO was injected into the spectrometry with a residence period of $6 \mathrm{sec}$. The GC/MS mass spectrum showed the presence of 12 different compounds at various retention times. The peaks of the of the GC/MS mass spectrum were detailed as fragmentation patterns and compared with standard NIST 1 and 2 libraries for the identification of compounds. Various peaks were seen on the mass spectrum between retention time 5.55 and $19.15 \mathrm{~min}$. RT 18.95 showed a highest peak of limonene with scan 716 and ions 2532. Limonene was considered to be the major compound of TPO as it is product of pyrolysing poly-isoprene [7]. Other major peaks were seen at retention time 17.17 and 5.55 which showed the presence of Bicyclo [2.2.1] heptan2-one, 3-(4-methoxybenzylidene)-1 7,7-trimethyl and
Cyclohexane 3 methyl-6-(1-methylethenyl) (3R-Trans) respectively in prominent quantities. Other than the major compounds Naphthalene, 1,2,4a,5,8,8a-hexahydro ,4,7dimethyl-1-(1-methylethyl) and Tricyclo [5.3.1.1(2,6)] dodecan-11-ol,11-methyl-12-methylene were also seen in the fragmentation pattern. The GC/MS mass spectrum generally revealed that tire pyrolysis oil mainly contain aliphatic and aromatic compounds with concentrations of $46.2 \%$ and $30.9 \%$ respectively. The gas chromatography mass spectrum is shown in Figure (5) and the various compounds present in the TPO is given in Table (4). The Fourier transform infrared analysis supports the GC/MS data $[7,9]$. 
Table 5 Composition of various compounds in TPO using GC/MS

\begin{tabular}{|c|c|c|c|c|}
\hline $\begin{array}{c}\text { Ret } \\
\text { Time } \\
\text { (min) }\end{array}$ & Name of the compound & $\begin{array}{l}\text { Chemical } \\
\text { formula }\end{array}$ & Scan & Ions \\
\hline 5.55 & Cyclohexane 3 methyl-6-(1-methylethenyl) (3R-Trans) & $\mathrm{C}_{6} \mathrm{H}_{12}$ & 186 & 1861 \\
\hline 10.27 & 1-Ethyltricyclo[5.2.1.1(2,6)]undue-8-en-11-ol & $\mathrm{C}_{2} \mathrm{H}_{3} \mathrm{~N}_{3} \mathrm{O}$ & 370 & 1830 \\
\hline 10.75 & Naphthalene, 1,2,3,4-Tetrahydro-2,5,8-Trimethyl & $\mathrm{C}_{10} \mathrm{H}_{8}, \mathrm{C}_{13} \mathrm{H}_{18}$ & 389 & 1881 \\
\hline 11.35 & 1,1,4a-Trimethyl-5,6-dimethylenedecahydronapthalene & $\begin{array}{l}\left(\mathrm{CH}_{3}\right)_{3} \mathrm{PO}_{4}, \\
\mathrm{C}_{11} \mathrm{H}_{2} \mathrm{O}\end{array}$ & 414 & 1900 \\
\hline 11.78 & Naphthalene, 1,2,4a,5,8,8a-hexahydro,4,7-dimethyl-1-(1-methylethyl) & $\mathrm{C}_{15} \mathrm{H}_{24}$ & 431 & 1938 \\
\hline 12.48 & Tricyclo[5.3.1.1(2,6)]dodecan-11-ol,11-methyl-12-methylene & $\mathrm{C}_{10} \mathrm{H}_{16}$ & 458 & 1940 \\
\hline 12.83 & Cycloheptene, 4-methoxy--phenyl & $\mathrm{C}_{14} \mathrm{H}_{18} \mathrm{O}$ & 475 & 1923 \\
\hline 14.65 & Bicyclo[3.1.0]hexan-2-one,6,6-dicyano-5-(1) & $\mathrm{C}_{6} \mathrm{H}_{10}$ & 544 & 1873 \\
\hline 16.95 & 1-Azatricyclo[7.3.0.0(2,7)]dodecan-11-ol-12-one, 8-methyl & $\mathrm{C}_{14} \mathrm{H}_{21}$ & 636 & 2001 \\
\hline 17.17 & Bicyclo[2.2.1]heptan-2-one, 3-(4-methoxybenzylidene)-1,7,7-trimethyl- & $\mathrm{C}_{16} \mathrm{H}_{20} \mathrm{~N}_{3}$ & 644 & 2066 \\
\hline 18.95 & Limonene & $\mathrm{C}_{19} \mathrm{H}_{36} \mathrm{~N}_{2}$ & 716 & 2532 \\
\hline 19.15 & 1-Phenyl-3-ethylprop-1-ene(1-3)sultine & $\mathrm{C}_{19} \mathrm{H}_{38} \mathrm{NH}_{2}$ & 723 & 2194 \\
\hline
\end{tabular}

Table (5) showed the presence of various functional group with respect to the wave-length frequency of Fourier transform infrared analysis. From the wave length spectrum is can be noticed that tire pyrolysis oil mainly contains aliphatic and aromatic compounds between $1380 \mathrm{~cm}-1$ and $1820 \mathrm{~cm}-1$ which was also revealed by GC/MS analysis. C-H stretch and C-H bend was also seen between 2720-2940 cm-
1 and 2985-3015 cm-1 wave length of FT IR analysis. The FT IR analysis also revealed the presence of alkenes, amines, alkanes, aldehydes and phenyl rings in prominent quantities which were favorable to be used as fuel in internal combustion engine [15].

Table 6 Comparison of Fuel Properties - TPO with Straight diesel and WPO

\begin{tabular}{|l|l|l|l|l|l|}
\hline \multicolumn{1}{|c|}{ Properties } & \multicolumn{1}{c|}{ Units } & \multicolumn{1}{c|}{$\begin{array}{c}\text { Testing } \\
\text { Methods }\end{array}$} & Straight Diesel & \multicolumn{1}{|c|}{ TPO } & \multicolumn{1}{c|}{ WPO } \\
\hline Density @ $15^{\circ} \mathrm{c}$ & $\mathrm{kg} / \mathrm{m}^{3}$ & IS:1448 P:16 & 830 & 934 & 835.5 \\
\hline Kinematic viscosity, @ $40^{\circ} \mathrm{c}$ & $\mathrm{Cst}$ & IS:1448 P:25 & 2 & 3.1 & 2.0 \\
\hline Flash point & ${ }^{\circ} \mathrm{c}$ & IS:1448 P:20 & 50 & 44 & 42 \\
\hline Fire point & ${ }^{\circ} \mathrm{c}$ & IS:1448 P:20 & 56 & 51 & 45 \\
\hline Gross Calorific value & $\mathrm{MJ} / \mathrm{kg}$ & IS:1448 P:6 & 43.8 & 42.9 & 40.17 \\
\hline Sulphur content & $\%$ & IS:1448 P:33 & 0.045 & 0.96 & 0.030 \\
\hline Carbon residue & $\%$ & IS:1448 P:122 & 0.35 & 2.15 & 82.49 \\
\hline Ash content & $\%$ & IS: 1448 P:126 & 0.01 & 0.32 & 0.00023 \\
\hline Cetane Index & - & IS: 1448 P:9 & 46.2 & 54 & 66 \\
\hline
\end{tabular}


Table 7 Comparison of Fuel Properties-TPO Straight diesel blends

\begin{tabular}{|l|l|l|l|l|l|}
\hline \multicolumn{1}{|c|}{ Properties } & \multicolumn{1}{c|}{ Units } & \multicolumn{1}{c|}{$\begin{array}{c}\text { TPO } \\
\mathbf{5}\end{array}$} & \multicolumn{1}{c|}{$\begin{array}{c}\text { TPO } \\
\mathbf{1 0}\end{array}$} & \multicolumn{1}{c|}{$\begin{array}{c}\text { TPO } \\
\mathbf{2 0}\end{array}$} & \multicolumn{1}{c|}{$\begin{array}{c}\text { TPO } \\
\mathbf{3 0}\end{array}$} \\
\hline Density @ $15^{\circ} \mathrm{c}$ & $\mathrm{kg}^{3}$ & 829 & 834 & 840 & 850 \\
\hline Kinematic viscosity, @ $40^{\circ} \mathrm{c}$ & $\mathrm{Cst}$ & 2.48 & 2.58 & 2.64 & 2.72 \\
\hline Flash point & ${ }^{\circ} \mathrm{c}$ & 44 & 46 & 42 & 38 \\
\hline Fire point & ${ }^{\circ} \mathrm{c}$ & 58 & 60 & 54 & 50 \\
\hline Gross Calorific value & $\mathrm{MJ} / \mathrm{kg}$ & 42.9 & 42.6 & 42.2 & 41.9 \\
\hline Sulphur content & $\%$ & 0.10 & 0.28 & 0.029 & 0.31 \\
\hline Carbon residue & $\%$ & 0.02 & 0.06 & 0.03 & 0.02 \\
\hline Ash content & $\%$ & 0.08 & 0.03 & 0.02 & 0.02 \\
\hline Cetane Index & - & 51 & 50 & 47 & 44 \\
\hline
\end{tabular}

The physio-chemical properties of tire pyrolysis oil in comparison with straight diesel and waste plastic oil are shown in Table (6). Indian standard 1448 testing method was adopted to determine properties like density, kinematic viscosity, flash \& fire point, calorific value, sulphur content, carbon residue, ash content and cetane index. The density of TPO was found to be 934 at $15^{\circ} \mathrm{C}$ which was comparably higher than straight diesel and WPO. The kinematic viscosity also showed a significant increase on comparing with straight diesel and WPO. The flash \& fire point was found to be $44^{\circ} \mathrm{C} \& 51^{\circ} \mathrm{C}$ were as straight diesel and WPO represented $50^{\circ} \mathrm{C} \& 56^{\circ} \mathrm{C}$ and $42^{\circ} \mathrm{C} \& 45^{\circ} \mathrm{C}$ respectively. The gross calorific value of TPO laid in-between straight diesel and WPO but the sulphur content showed an enormous increase by more than $21.3 \%$ than straight diesel which confirms the necessity of de-sulphurisation process. The cetane index was found to be 54 which were higher than straight diesel and lower than WPO. The $\mathrm{pH}$ value of TPO was noticed to be marginally acidic which make it difficult to handle and storage $[6,15]$.

The blends of TPO with straight diesel at 5\%, 10\%, 20\% and $30 \%$ are shown in Table (7) which gives us an idea of its usage in internal combustion engines. It can be seen that with increase in tire pyrolysis blend with straight diesel, density, kinematic viscosity, flash \& fire point, sulphur content and carbon residue was increased were as gross calorific value and cetane index represented a decreasing trend. From the table it is evident that more quantity of TPO will be required to get a similar power output of straight diesel.

\section{CONCLUSION}

From the present experimental investigation, following conclusions were derived,

* Pyrolysis process was one of the best methods to treat waste tire under solid waste management technique.

* A pyrolysis batch reactor was successfully designed and fabricated with a handling capacity of $10 \mathrm{kgs}$ per cycle and the overall yield of TPO was found to be $42 \%$. Yield of TPO was noticed at higher levels with the increase in temperature above $450^{\circ} \mathrm{C}$.

* De-moisturizing, de-sulphurisation, and distillation process were carried out to remove excess moisture, sulphur removal and sludge isolation in the presence of $10 \%$ concentrated $\mathrm{H}_{2} \mathrm{SO}_{4}$. By this process $92 \%$ of distilled TPO was recovered.

* The elemental analysis revealed the presence of carbon, hydrogen, sulphur and oxygen at $81.48 \%, 6.22 \%, 1.68 \%$ and $7.69 \%$ respectively.

* The GC/MS analysis showed evidence of Limonene presence at major quantity along with many aliphatic and aromatic compounds with FT IR analysis as confirmatory and support.

* The physio-chemical properties of treated TPO were found to be comparable with straight diesel with higher sulphur content. The blends of TPO and straight diesel also showed improvements in density, kinematic viscosity, flash \& fire point and carbon residue with a marginal decrease in cetane index and calorific value.

\section{ACKNOWLEDGEMENTS}

The author would like to acknowledge Sophisticated Analytical Instrumentation Facility (SAIF), Indian Institute of Technology Madras and ITA lab Chennai for the support in analyzing the properties of tire pyrolysis oil.

\section{REFERENCES}

[1] Cao Q, Jin LE, Bao WR, Lu YK. Factors influencing the quality of pyrolytic oil from used tires. Energy sources Part A 2008; 30: 833-841.

[2] Chang Y. On pyrolysis of waste tyre degradation rate and product yields. Resource, Conservation and recycling 1996; 17: 125-139.

[3] Debalaxmi Pradhan and Singh RK. Thermal pyrolysis of bicycle waste tyre using batch reactor. International Journal of Chemical engineering and applications 2011; 2(5): 332-336.

[4] Elena Cristina Rada, Marco Ragazzi, Roberto Dal Maschio, Mario Ischia, Valeriu Nicolae Panaitescu. Energy recovery from tyre waste through thermal options. U.P.B.Sci.Bull, Series D 2012; 74: 201-210.

[5] Islam MR, Islam MN, Mustafi NN, Rahim MA and Haniu H. Thermal recycling of solid tire waste for alternative liquid fuel: the first commercial step in Bangladesh. Procedia Engineering 2013; 56:573-582. 
[6] Islam MR, Haniu H, Beg Alam MR. Liquid fuels and chemicals from pyrolysis of motorcycle tyre waste product yields, composition and related properties. Fuel 2008; 87: 3112-3122.

[7] Laresgoiti MF, Caballero BM, De Marco I, Torres A, Cabero MA and Chomon MJJ. Characterization of liquid products obtained in tire pyrolysis. J.Ann.App.Pyrolysis 2004; 71: 917-934.

[8] Murugan S, Ramaswamy MC and Nagarajan G. A comparative study on the performance, emission and combustion studies of a DI diesel engine using distilled tyre pyrolysis oil-diesel blends. Fuel 2008; 87(10-11): 2111-2121.

[9] Mirmiran S, Pakdel H. Roy C. Characterization of used tire vacuum pyrolysis oil: Nitrogenous compound from the naptha fraction. J. Anal. Appl. Pyrolysis 1992; 22: 205-215.

[10] Morillo R, Aylon E, Navarro MV, Callen MS, Aranda A, Mastral AM. The application of thermal processes to valorize waste tyre. Journal of Fuel Processing Technology 2006; 87: 143-147.

[11] Rofiqul Islam M, Praveen M, Haniu H, Islam Sarkar MR. Innovation in pyrolysis technology for management of scrap tire: a solution of energy and environment. Int. J.Env. Sci.and Engg.2010; 1(1): 8996.

[12] Sharma VK, Mincarini M, Fortuna F, Cognini F and Cornacchia G. Disposal of waste tires for energy recovery and safe environment-review. Ene. Con. and man. 1998; 39:511-528.

[13] Suhanya M, Thirumasrmurugan M, Kannadasan T. Recovery of oil form waste tyres using pyrolysis method: a review. International Journal of research in Engineering \& Technology 2013; 1(2): 81-89.

[14] Taxin Su, Liming Ren, Wenyi Deng. Experimental study on NO reduction by reburning of waste tire. Procedia Env. Sci. 2013; 18: 359-365.

[15] Williams PT, Beeseler S. Pyrolysis thermogravimetric analysis of tyre and tyre components. Fuel 1995; 74: 1277-1283.

[16] Williams PT, Brindle AJ. Temperature selective condensation of tyre pyrolysis oils to maximize the recovery of single ring aromatic compounds. Fuel 2003; 82: 1023-1031.

[17] Williams PT, Waste treatment and disposal, $2^{\text {nd }}$ edition; Wiley \& Sons, London 2005. 